\title{
Change of niche in guanaco (Lama guanicoe): the effects of climate change on habitat suitability and lineage conservatism in Chile
}

\author{
Andrea G Castillo ${ }^{1}$, Dominique Alò ${ }^{1,2}$, Benito A González ${ }^{3}$, Horacio Samaniego ${ }^{\text {Corresp. } 1}$ \\ 1 Laboratorio de Ecoinformatica, Universidad Austral de Chile, Valdivia, Los Ríos, Chile \\ 2 Pontificia Universidad Católica de Chile, Departamento de Ecología, Santiago, Chile \\ 3 Laboratorio de Ecología de Vida Silvestre / Facultad de Ciencias Forestales y de la Conservación de la Naturaleza, Universidad de Chile, Santiago, Chile \\ Corresponding Author: Horacio Samaniego \\ Email address: horacio@ecoinformatica.cl
}

Background. The main goal of this contribution was to define the ecological niche of the guanaco (Lama guanicoe), to describe potential distributional changes, and to assess the relative importance of niche conservatism and divergence processes between the two lineages described for the species (L.g. cacsilensis and L.g. guanicoe).

Methods. We used maximum entropy to model lineage's climate niche from 3,321 locations throughout continental Chile, and develop future niche models under climate change for two extreme greenhouse gas emission scenarios (RCP2.6 and RCP8.5). We evaluated changes of the environmental niche and future distribution of the largest mammal in the Southern Cone of South America. Evaluation of niche conservatism and divergence were based on identity and background similarity tests.

Results. We show that: a) the current geographic distribution of lineages is associated to different climatic requirements that are related to the geographic areas where these lineages are located; $b$ ) future distribution models predict a decrease in the distribution surface under both scenarios; c) a $3 \%$ decrease of areal protection is expected if the current distribution of protected areas is maintained, and this is expected to occur at the expense of a large reduction of high quality habitats under the best scenario; d) current and future distribution ranges of guanaco mostly adhere to phylogenetic niche divergence hypotheses between lineages.

Discussion. Associating environmental variables to species ecological niche seems to be an important aspect of unveiling the particularities of, both evolutionary patterns and ecological features that species face in a changing environment. We report specific descriptions of how these patterns may play out under the most extreme climate change predictions and provide a grim outlook of the future potential distribution of guanaco in Chile. From an ecological perspective, while a slightly smaller distribution area is expected, this may come with an important reduction of available quality habitats. From the evolutionary perspective, we describe the limitations of this taxon as it experiences forces imposed by climate change dynamics. 


\section{Change of niche in guanaco (Lama guanicoe): The effects of}

2 climate change on habitat suitability and lineage conservatism

3 in Chile

4 Andrea G Castillo ${ }^{1}$, Dominique Alò ${ }^{1,2}$, Benito A. González ${ }^{3}$, Horacio Samaniego ${ }^{1}$

51 Laboratorio de Ecoinformática,

6 Instituto de Conservación, Biodiversidad y Territorio,

7 Universidad Austral de Chile, Valdivia, Los Ríos, Chile

8 2Departamento de Ecología, Pontificia Universidad Católica de Chile, Santiago, Chile

$9{ }^{3}$ Laboratorio de Ecología de Vida Silvestre,

10 Facultad de Ciencias Forestales y de la Conservación de la Naturaleza,

11 Universidad de Chile, Santiago, Chile

12

13 Corresponding Author:

14 Horacio Samaniego ${ }^{1}$

15 Laboratorio de Ecoinformática

16 Instituto de Conservación, Biodiversidad y Territorio

17 Universidad Austral de Chile

18 Campus Isla Teja s/n, Valdivia, Los Ríos, Chile

19 Email address: horacio@ecoinformatica.cl 
20 ABSTRACT

21 Background. The main goal of this contribution was to define the ecological niche of the 22 guanaco (Lama guanicoe), to describe potential distributional changes, and to assess the 23 relative importance of niche conservatism and divergence processes between the two lineages 24 described for the species (L.g. cacsilensis and L.g. guanicoe).

25 Methods. We used maximum entropy to model lineage's climate niche from 3,321 locations 26 throughout continental Chile and develop future niche models under climate change for two 27 extreme greenhouse gas emission scenarios (RCP2.6 and RCP8.5). We evaluated changes of the 28 environmental niche and future distribution of the largest mammal in the Southern Cone of 29 South America. Evaluation of niche conservatism and divergence were based on identity and 30 background similarity tests.

31 Results. We show that: a) the current geographic distribution of lineages is associated to 32 different climatic requirements that are related to the geographic areas where these lineages 33 are located; b) future distribution models predict a decrease in the distribution surface under 34 both scenarios; c) a 3\% decrease of areal protection is expected if the current distribution of 35 protected areas is maintained, and this is expected to occur at the expense of a large reduction 36 of high quality habitats under the best scenario; d) current and future distribution ranges of 37 guanaco mostly adhere to phylogenetic niche divergence hypotheses between lineages.

38 Discussion. Associating environmental variables to species ecological niche seems to be an 39 important aspect of unveiling the particularities of, both evolutionary patterns and ecological 40 features that species face in a changing environment. We report specific descriptions of how 41 these patterns may play out under the most extreme climate change predictions and provide a 42 grim outlook of the future potential distribution of guanaco in Chile. From an ecological 43 perspective, while a slightly smaller distribution area is expected, this may come with an 44 important reduction of available quality habitats. From the evolutionary perspective, we 45 describe the limitations of this taxon as it experiences forces imposed by climate change 46 dynamics. 


\section{Introduction}

48 Human induced climate change is imposing severe challenges to the equilibrium of natural 49 ecosystem functioning (IPCC, 2013). Organisms will either have to face extinctions or adapt 50 (Berg et al., 2010) by altering their seasonal activities, home ranges, migratory patterns,

51 abundances, and interspecific interactions (Lenoir et al., 2008; Araújo, Thuiller \& Yoccoz, 2009;

52 Elith \& Leathwick, 2009; Pecl et al., 2017). Global rise of temperatures will likely accelerate 53 extinction risks and threaten up to one in every six species (Urban, 2010). Studies on the impact

54 of climate change on ungulates have shown that changes in distribution ranges include 55 altitudinal shifts in mountain environments (Mason et al., 2014) and distributional shifts 56 towards equivalent habitats (Hu \& Jiang, 2011). In more extreme cases, local extinctions will be

57 driven by environmental aridization (Thuiller et al., 2006; Duncan et al., 2012).

58 In Chile, current projections of greenhouse gas emissions proposed by the Intergovernmental

59 Panel on Climate Change (IPCC) indicate that temperature will increase in a North to South 60 gradient (IPCC, 2013). A large $2.5^{\circ} \mathrm{C}$ increase is expected in the Altiplano under the most 61 extreme emission scenario and a milder $0.5^{\circ} \mathrm{C}$ increase is projected in the southern region of 62 Magallanes for the period 2031-2050. Additionally, a 10-15\% decrease in precipitation is 63 expected in the middle of the country (between $25^{\circ}$ and $45^{\circ} \mathrm{S}$ ), while forecasting a $5 \%$ rainfall

64 increase in Patagonia and a similar snowfall decrease in the Magallanes region (Rojas, 2012).

65 The guanaco (Lama guanicoe) is both the most abundant native ungulate and the largest (120

$66 \mathrm{~kg}$ ) artiodactyl in South America (Franklin, 1982). The species is widely distributed throughout

67 the Southern Cone, inhabiting cold, arid, and semi-arid environments from sea level up to 5,000 
68

69

70

71

72

73

74

75

76

77

78

79

80

81

82

83

84

85

86

87

88 89

$\mathrm{m}$ a.s.l. extending from northwestern Peru to Tierra del Fuego and Isla Navarino in the southern tip of the continent, with small populations roaming east of the Andes in the arid Chaco of Bolivia and Paraguay (Franklin, 1982; González et al., 2006). Highest population densities are found in the Andes and in Patagonia (Baldi et al., 2016). The species is characterized by specific anatomical, physiological, and reproductive adaptations to thrive and survive in arid environments despite the intense competition with livestock and severe degradation of their habitat (González et al., 2013; Marin et al., 2013; Baldi et al., 2016). The guanaco has a defined ecological role in each of its ecoregions either controlling vegetation growth or dispersing seeds (González et al., 2006). These characteristics make the guanaco an important element within the trophic chain. For instance, it is the main prey of the puma (Puma concolor) (Franklin et al., 1999) and is the target of scavengers such as the chilla fox (Lycalopex griseus), the culpeo fox (Lycalopex culpeus) and the Andean condor (Vultur gryphus) among others (Travaini et al., 2001; González et al., 2006).

Two distinct subspecies of guanaco (L.g. cacsilensis and L.g. guanicoe) have been proposed based on genetic studies. L.g. cacsilensis is distributed to the west of the Central Andean Plateau throughout Peru and the northern tip of Chile with occurrences mostly explained by elevation and precipitation seasonality. L.g. guanicoe is found on the southeastern slope of the Andes, ranging throughout Patagonia and Tierra del Fuego with occurrences mostly explained by annual precipitation, precipitation seasonality and grass cover (González et al., 2013; Marin et al., 2013, 2017). The geographical limit between the northwestern and southeastern lineages has been proposed to occur around $31^{\circ} \mathrm{S}$ in Chile (Marin et al., 2017) and the significant genetic structure found among the two guilds has led to recommend to classify the two lineages as 
90

91

92

93

94

evolutionary significant units (ESUs) following Moritz's (1994) criteria (González et al., 2013;

Marin et al., 2013). However, the two lineages are not completely separated from each other.

In fact, some populations have individuals of both lineages forming zones of mixed genetic heritage (Marin et al., 2013). The distribution of this mixed population was predicted to occur at the south end of the Altiplano, between $26^{\circ} \mathrm{S}$ and $32^{\circ} \mathrm{S}$ approximately, and is better explained by annual precipitation and precipitation seasonality (González et al., 2013). As reported by Marin et al., (2013), the Andean plateau could have acted as a biogeographical and ecological barrier fostering vicariance processes that may be at the origin of the current distribution of guanaco lineages. It is presumed that climate changes that occurred in the past, allowed the establishment of populations over this geographic barrier, with periods of connectivity and isolation allowing the establishment of populations with mixed genetic heritage (Marin et al., 2013).

While the discontinuity of the current geographical distribution of guanaco is mostly a consequence of recent human activities (González et al., 2006), the macroevolutionary processes leading to lineage divergence in guanaco should be taken into consideration when deciding on the conservation actions required, as it has been discussed elsewhere for other species (Hu et al., 2015). Current threats are mostly related to high competition for fodder with cattle and introduced mammals (Mason et al., 2014); predation by feral dogs, illegal hunting, and the reduction of available habitat due to the intensification of agriculture (González et al., 2006; Baldi et al., 2016). The 14.5 million hectares protected by the Chilean System of

Protected Areas does not cover the entire species range (Baldi et al., 2016), prompting important questions regarding the future distribution of guanaco. Mostly, L. guanicoe is well 
112 adapted to a wide variety of habitats (González et al., 2006, 2013). However, at the intraspecific

113 level, each lineage may respond differently to changes. As evidence from guanaco's natural

114 history indicates, past changes in climate have clearly influenced the geographic distribution of

115 this species, particularly in the Altiplano and Puna where guanacos and vicuñas (Vicugna

116 vicugna) compete for resources since the Holocene (Marin et al., 2013, 2017). Thus, under the

117 possible climate change scenarios in Chile, we expect L.g. cacsilensis to expand (or to shift)

118 southward and overlap with the mixed genetic heritage population. On the other hand, we

119 predict that L.g. guanicoe, characterized by a wider climatic tolerance (González et al., 2013),

120 should mostly maintain its current geographic distribution.

121 From an evolutionary perspective, given the existence of these two lineages and the repeated

122 suggestions of their consideration as ESUs (Marin et al., 2013; Baldi et al., 2016), it would be of

123 great interest to evaluate the state of conservation of their niche to support with new evidence

124 this classification. From such perspective, it becomes relevant to assess whether phylogenetic

125 niche conservatism (PNC), the tendency of closely related species to differ less ecologically than

126 expected by chance, or otherwise, phylogenetic niche divergence (PND), the tendency of

127 closely related species to differ more ecologically than expected by chance may prevail under

128 current and predicted niche segregation patterns under future climate change (Pyron et al.,

129 2015; Meynard et al., 2017).

130 Based on the latest projections of climate change in the region (Rojas, 2012; IPCC, 2013) and

131 the understanding of L. guanicoe taxonomy and life history, we developed models based on

132 niche theory to assess the impact of climate change on guanaco's ESUs. By modeling the niche

133 of L. guanicoe and its lineages we here: a) estimated their current geographic distribution based 
134 on bioclimatic variables; b) predicted their future distribution based on the projections of the

135 best and worst climate change scenario at two different time frames (2050, 2070); c) quantified

136 the area predicted to be gained, lost, or remain stable in the future for both guanacos lineages

137 and mixed population; d) evaluated and compared how much of the Chilean protected areas

138 will overlap with the future distribution area calculated for guanacos; and e) explored the

139 existence of niche conservatism or divergence between $L$. guanicoe lineages, in terms of their

140 niche equivalence (Graham et al., 2004) and similarity (Peterson, Soberón \& Sánchez-cordero, 141 1999).

\section{METHODS}

\section{Species occurrence data}

144 We built a guanaco occurrence dataset of 3,321 records by complementing previous work by

145 the authors with 359 additional records (González et al., 2013). New records were collected

146 following the same procedures outlined in González et al., (2013), that is, from direct and

147 indirect evidence of guanaco presence collected between the years 2000 and 2016 across

148 several field campaigns. Indirect evidence of guanaco occurrence was assigned to a lineage by

149 genetic and morphological evaluation of biological samples such as feces and dead tissues.

150 Most of new records were collected in the northern section of the country in the Arica,

151 Parinacota (i.e. $17^{\circ} \mathrm{S}$ latitude) and Coquimbo region $\left(30^{\circ} \mathrm{S}\right)$. Each record was assigned to a

$1521 \times 1 \mathrm{~km}$ cell defined by the resolution of the environmental datasets employed (see below). This

153 resulted in a total of 298 records for L.g. cacsilensis, 837 for the mixed population, and 2186 for 154 L.g. guanicoe. 
155

156

157

158

159

160

161

162

163

164

165

166

167

168

169

170

171

172

173

174

175

\section{Climate predictors}

We limited the selection of environmental predictors to climatic variables (Thuiller et al., 2006;

Hu et al., 2015). Similarly to what has been described in the literature (Thuiller et al., 2004), our previous work dismissed the importance of non-climate predictors for guanaco distribution models in favor of exclusive climatic variables (González et al., 2013). We used all 19 bioclimatic variables from WorldClim (version 1.4) summarizing temperature and precipitation information worldwide (Hijmans et al., 2005). To reduce collinearity, model overfitting, and the number of explanatory variables, we used a paired correlation analysis to inspect pairs of variables and removed variables with large correlation coefficient (>0.8) (Beaumont, Hughes \& Poulsen, 2005).

While the analysis was limited to the administrative bounds of Chile, all WorldClim variables were projected to UTM 19 South, with a 1 squared-km of spatial resolution, spanning from latitudes $15^{\circ} \mathrm{S}$ to $55^{\circ} \mathrm{S}$ and longitudes $60^{\circ} \mathrm{W}$ to $80^{\circ} \mathrm{W}$ and a total area of $5,921,578 \mathrm{~km}^{2}$ covering most of the Southern Cone.

\section{Future Climate Projections}

The projection of future geographic distribution of niches was performed using the outputs of the Coupled Model Intercomparison Project 5 (CMIP5) of the IPCC's methodology for the Fifth Assessment Report (AR5) (Taylor, Stouffer \& Meehl, 2012). The two extreme greenhouse gas (GHG) concentration scenarios, also known as Representative Concentration Pathway (RCP), were used to project future climate niches. RCP2.6, the most optimistic scenario, considers a

lower GHG concentration and projects average increases of temperature between $0.3^{\circ}$ to $1.6^{\circ} \mathrm{C}$ 
176 with 0.26 to $0.55 \mathrm{~m}$ increases of sea levels. RCP8.5, the most pessimistic scenario, considers

177 higher GHG concentrations with a $2.6^{\circ}$ to $4.8^{\circ} \mathrm{C}$ projected increase in mean global temperature

178 and a 0.45 to $0.82 \mathrm{~m}$ rise of sea levels (IPCC, 2013). We chose both extreme scenarios to

179 evaluate the minimum and maximum potential impact of climate change in the guanaco's

180 distribution.

181 Given the large uncertainties of future climate predictions, the computing power availability

182 and the exploratory nature of such models, we selected five General Circulation Models (GCM)

183 among the 19 models used to generate the AR5. GCM's are physical climate models that

184 simulate the interactive biophysical processes between the atmosphere, the ocean and the

185 land (Moss et al., 2010). Selected climate models were: (1) CCSM4 model of the National Center

186 of Atmospheric Research (Gent et al., 2011); (2) GFDL-CM3 model of the Geophysical Fluid

187 Dynamics Laboratory (Donner et al., 2011); (3) GISS-E2-R model of the NASA Goddard Institute

188 for Space Studies (Nazarenko et al., 2015); (4) HadGEM2 - AO atmosphere model and (5)

189 HadGEM2 - ES earth system model, both of the Met Office Hadley Centre (Collins et al., 2011).

190 Each scenario was evaluated for the short (2050) and medium term (2070).

191 Niche Modeling

192 Entropy maximization procedures in MaxEnt 3.3.3 k (Phillips, Anderson \& Schapire, 2006) were

193 used to model current and future geographic distributions of L. guanicoe and its lineages.

194 MaxEnt uses a machine learning algorithm to generate predictions on the potential distribution

195 of species based on their presence, pseudo-absences and a set of environmental variables. The

196 software analyzes the multivariate distribution of environmental conditions of species

197 occurrences to generate a spatially explicit probability map of lineage occurrence (Franklin, 
198 2009). Such modelling approach has shown to have a good statistical performance compared to

199 other types of modeling techniques (Elith et al., 2006) and is currently one of the most

200 commonly used methods to understand habitat suitability, niche structure, geographical

201 species distribution (Merow, Smith \& Silander, 2013a) as well as to project environmental

202 niches to future scenarios (Hijmans \& Graham, 2006).

203 We performed 100 cross-validated replicates for each current and projected distribution model

204 with logistic output, that unlike other outputs (i.e. raw and cumulative) assumes that a known

205 observation probability can be assigned to each pixel and has thus been considered as a true

206 approximation of presence (Merow, Smith \& Silander, 2013a). The "fade by clamping" option

207 was used to avoid predictions beyond the observed geographical range during the training of

208 the future distributions model (Phillips, Anderson \& Schapire, 2006). All other parameters were

209 kept at their default configuration (Phillips, Dudík \& Schapire, 2004) as they have previously

210 shown good performance in ungulate modeling (Hu \& Jiang, 2011; González et al., 2013; Hu et

211 al., 2015; Quevedo et al., 2016) and other taxonomic groups (Phillips \& Dudík, 2008; Fourcade

212 et al., 2014).

213 We used an ensemble forecasting framework to minimize the inherent variability introduced by

214 the various forecast models employed, as proposed by Araújo and New (2007). Therefore, we

215 generated a model from the average of each bioclimatic variable produced by the five GCMs

216 (i.e. $B i o 1_{\mathrm{CC}}+\mathrm{Bio}_{\mathrm{GF}} \mathrm{Bio} 1_{\mathrm{GS}}+\mathrm{Bio} 1_{\mathrm{HD}}+\mathrm{Bio} 1_{\mathrm{HE}}$ ), and then evaluated an average value for each

217 variable from one hundred replicates for both extreme RCP emission scenarios for the years

2182050 and 2070. Hence, 400 projected guanaco distribution models were generated (i.e. 2 RCPs 
$219 \times 2$ time frames $\times 100$ replicates). The final results are four projected climate models for $L$.

220 guanicoe, one for each RCP2.6 and RCP8.5 scenarios evaluated for years 2050 and 2070.

\section{Model evaluation, prediction and spatial projection}

222 Generated niche models were evaluated using a threshold-independent analysis of the area

223 under the curve (AUC) provided by the Receiver Operator Curve (ROC) (Phillips, Anderson \&

224 Schapire, 2006; Acevedo et al., 2010; Anderson \& Raza, 2010). These sensitivity tests model

225 accuracy by calculating the proportion of true positives versus false positives. The resulting

226 values range from 0 to 1, where model predictions are considered fair when obtained AUC

227 values are above 0.7 (Swets, 1988; Merow, Smith \& Silander, 2013b). A 3:1 ratio was used to

228 divide training and testing datasets (Phillips, Anderson \& Schapire, 2006). AUC Jackknife

229 analysis allowed to identify the contribution of each variable to final current and future models,

230 and to allow the detection of those variables that significantly improve predictions for the

231 occurrences of each lineage (Phillips, Anderson \& Schapire, 2006).

232 We reclassified predicted habitat using a 0.25 threshold interval to label three habitat suitability

233 classes: low suitability habitat when occurrence probability ranged between 25 and 50\%;

234 suitable habitat if occurrence probability was in the 50 to $75 \%$ interval; and high suitability

235 habitat if occurrence probability was over $75 \%$, values below $25 \%$ were considered as

236 inappropriate habitat (Hu \& Jiang, 2012; González et al., 2013; Shrestha \& Bawa, 2014).

\section{Changes in distribution surface and incidence in protected areas}

238 The areal extent for each suitability class predicted by each model, current and projected, were

239 compared to determine habitat loss (or gains) under the various climate change scenarios 
240 evaluated. We used the software BioSARN v.1 to calculate the amount of area gained or lost

241 and to estimate differences between models (Heap, 2016). These results were classified into

242 three categories: (a) Areal loss, when future prediction show a decrease of the areal extension

243 compared to current niche models; (b) Areal gain, produced when future prediction add area to

244 current niche models; (c) Unchanged areas, when climate change predictions show no impact

245 on current guanaco's distribution.

246 In addition, the fraction of future distribution covered by the system of protected area in Chile

247 (PA) was estimated. All categories offering some level of protection were considered: national

248 parks, national reserves, biosphere parks, national monuments, national patrimony, and private

249 PA as of 2011. RAMSAR sites (as of 2012) were also included as they constitute the most

250 important feeding grounds for guanaco in the hyper-arid north of Chile (Squeo et al., 2006).

\section{Evaluation of PNC or PND}

252 PNC and PND among lineages and the mixed population were evaluated through their current

253 and projected niches for the most extreme scenario (i.e. RCP8.5) in 2070 using ENMTools

254 v.1.4.3 (Warren, Glor \& Turelli, 2010). Niche overlap between lineages was calculated with the

255 statistical indices "I" (derivative of Hellinger's distance) and " $D$ " (Shöener's D) which may take

256 values going from 0 (i.e. no overlap) to 1 (i.e. full overlap between lineages' niches). We used

257 the Identity test to evaluate the hypothesis of niche equivalence (Graham et al., 2004) and the

258 Background similarity test to evaluate the hypothesis of niche similarity (Peterson, Soberón \&

259 Sánchez-cordero, 1999). Identity test quantitatively assesses whether the niche space for two

260 compared lineages are equivalent by comparing the actual niche to a null niche model

261 generated from a randomized pool of locations for each lineage. This allows to effectively 
262 evaluate whether niche spaces are equal, under the premise that, if they are, they should be

263 able to predict each other (Warren, Glor \& Turelli, 2010). Because the identity test strongly

264 depends on accurate representations of species habitat suitability, it is known to be sensitive to

265 the particular sampling scheme employed, and therefore less suitable to compare allopatric

266 niches (Warren, Glor \& Turelli, 2010). The Background similarity test compares the niche

267 difference between allopatric lineages by contrasting the niche of a "focal" lineage to the niche

268 built from the background locations of a second lineage. If there is similarity between these, the

269 null model should predict the niche of the second lineage. We repeated each test 100 times to

270 produce a simulated distribution of $I$ and $D$ values and to evaluate significance using a threshold

271 of 0.1 (two-tailed for background similarity test, and one-tail for Identity test) (Warren, Glor \&

272 Turelli, 2010; Guisan, Thuiller \& Zimmermann, 2017). We considered outcomes as indicative of

273 PNC between lineages when observed $I$ and $D$ values fell within the simulated distribution. On

274 the other hand, when the observed values fell outside of the simulated distribution, they were

275 assumed to be indicative of PND between lineages.

\section{Results}

\section{Selection of climate variables and current distribution model}

278 After removing correlated variables, the final subset of independent bioclimatic variables used

279 in this analysis was composed of: annual mean temperature (Bio1), temperature seasonality

280 (Bio4), annual temperature range (Bio7), annual precipitation (Bio12) and precipitation

281 seasonality (Bio15). See correlation analysis in supplemental Fig. S1. 
282 The major contribution to the current distribution of $L$. guanicoe was given by the annual range

283 of temperature (28.2\%, AUC $=0.84)$, whereas L.g. cacsilensis was dominated by precipitation

284 seasonality $(66.7 \%, A \cup C=0.95)$, the mixed population by annual precipitation $(36.7 \%, A \cup C=$

285 0.93), and the southernmost L.g. guanicoe was mostly driven by annual mean temperature

$286(35.8 \%, A \cup C=0.91)$. Detailed Jackknife's analysis can be seen in supplemental information, Fig.

287 S2.

288 All current distribution models generated for L. guanicoe and its lineages, presented a good

289 performance with mean AUC values over 0.89. The resulting geographic range for guanaco

290 spanned for about a third of the Chilean continental surface. The geographic areas covered by

291 L.g. cacsilensis and L.g. guanicoe were of 47,148 and 100,539 $\mathrm{km}^{2}$ respectively. The mixed

292 population showed a geographic extent of $84,976 \mathrm{~km}^{2}$. Interestingly, our models had a $20 \%$

293 difference when comparing areas from the sum of lineages modeled independently and the

294 total area modeled with all the lineages pooled as if they were a single lineage $\left(232,664 \mathrm{~km}^{2} \mathrm{vs}\right.$.

295 284,499 $\mathrm{km}^{2}$ respectively). Full maps and predictions are available in supplemental information

296 Fig. S3.

\section{Projected distribution models}

298 As for current distribution models, the sensitivity analysis yielded a large mean AUC > 0.9. After

299 suitability categorization (Fig. 1), our results show that while the geographical distribution

300 pattern of guanaco is conserved, quantitative assessment of the distribution surface reveals a

301 downward trend in both scenarios of climate change for 2050 and 2070 (Table 1). 
302 Marginal decreases of habitat suitability is observed under the RCP2.6 scenario for the years 3032050 and $2070\left(259,577 \mathrm{~km}^{2}\right.$ vs. $254,979 \mathrm{~km}^{2}$ respectively). The small areal reduction under 304 both models is only of $6 \%$ and $7.6 \%$ of the current area. However, this decrease is more 305 pronounced under the RCP8.5 scenarios in which a $13 \%$ and $20.7 \%$ reduction is quantified for 306 the years 2050 and 2070 respectively (i.e. $240,505 \mathrm{~km}^{2}$ and $218,841 \mathrm{~km}^{2}$ ).

\section{Surface change between current and projected distribution models}

Projected distribution models under the more optimistic scenario showed an increase of high quality habitat and a net loss of medium and low quality habitat, while the projections under the worst scenario indicate a generalized decrease in habitat suitability. Although no important loss of potential distribution areas are apparent, a large decrease of areas with high quality habitat may occur under the worst climate change scenario evaluated (Table 1). scenarios showed that a large fraction of the guanaco range will remain unchanged. The more optimistic projection (i.e. RCP2.6) indicated an average loss of $67,042 \mathrm{~km}^{2}$ between 2050 and 2070, and a niche displacement (i.e. gain) of $48,225 \mathrm{~km}^{2}$ on average between such time periods.

317 A reversed trend was observed under the more pessimistic scenario (i.e. RCP8.5) with the larger change predicted for 2070 . Such prediction forecasts a reduction in guanaco's niche by $37 \%$,

319 with a surface loss of $103,367 \mathrm{~km}^{2}$ and a geographic distribution of $172,786 \mathrm{~km}^{2}$. Likewise, the smallest niche displacement was observed for this period, with 46,089 km² of areal gain (Fig. 2).

\section{Evaluation of PNC and PND}


322 Niche overlap and equivalence tests showed a large overlap between the contact population

323 and L.g. cacsilensis for niche models under current and worst scenarios (Table 3). While limited

324 niche overlap was reported, the overlap between the northern lineage and the mixed

325 population increased under future climate change scenarios. On the other hand, the overlap

326 between current and projected niches for L.g. guanicoe with the other groups was smaller,

327 particularly with the northern lineage (L.g. cacsilensis). When using the results of this latter

328 analysis as "empirical values" to perform identity and background similarity tests (Table 3 and

329 Table 4), we were able to show that statistical differences existed when comparing current

330 niches and projected niches. This indicates that the climatic requirements between the lineages

331 and mixed population are not equivalent.

332 Background similarity test showed that L.g. cacsilensis share climatic similarities with the mixed

333 population (Table 4). However, such similarity is not reciprocal when comparing the climatic

334 requirements of the mixed population to those of the northern lineage -a possibility

335 mentioned in Warren, Glor \& Turelli (2010). A similar situation occurred when comparing

336 projected niches under the worst climate change scenario (RCP8.5), where results suggested

337 that L.g.guanicoe's niche will closely resemble the future climatic niche of the mixed

338 population, in spite of not sharing any current similarity.

339 The remaining comparisons between climatic niches, current and future, showed that the

340 climatic requirements for each of the lineages analyzed are significantly different (Table 4). 


\section{Projected distribution models and conservation in Chile}

342 The current network of PA in Chile covers a vast area of approximately $256,550 \mathrm{~km}^{2}$, according

343 to 2016 data, and shows a limited overlap with modeled guanaco distribution. In fact, our

344 analysis shows that a $9.8 \%$ (i.e. $19,402 \mathrm{~km}^{2}$ ) of the species current distribution overlaps with a

345 PA. When looking at projected distributions for 2070, our results showed that such overlap will

346 decrease to $6.2 \%\left(15,772 \mathrm{~km}^{2}\right)$ under the best scenario (RCP2.6). Similarly, under the worst

347 scenario (RCP8.5), the overlap will be of $5.7 \%\left(12,434 \mathrm{~km}^{2}\right)$ (Fig. 3).

\section{Discussion}

349 Understanding species' response to climate change is crucial in order to adequately manage

350 conservation efforts (Thomas et al., 2004; Araujo \& Rahbek, 2006; Warren et al., 2013). Several

351 authors have already warned about the dire consequences of climate change on ecosystems

352 and across a wide range of taxa (Walther et al., 2002; Quintero \& Wiens, 2013; Muñoz-

353 Mendoza et al., 2017). Our worst-case scenario analysis suggests that the guanaco will have lost

354 up to a fifth ( $21 \%$ ) of its current geographic distribution by 2070 . Although predicted changes

355 will barely be noticeable, the classification and quantification of suitable habitat provided

356 substantial insights on the vulnerability of this species to climate change showing that such

357 changes will additionally result in a confinement to sub-optimal quality habitats supporting

358 general trends outlined in the literature (Urban, 2010; Pecl et al., 2017). In particular, our

359 quantification of areal changes between current and future distribution under the worst-case

360 scenario, suggested an average loss of $34 \%$, compared to $17 \%$ of areal gains (i.e. new

361 distribution areas available) between 2050 and 2070. 
362 Our analysis strongly associated the northern lineage L.g. cacsilensis to precipitation seasonality

363 and predicted a southward shift in the future distribution of guanaco. However, our model

364 outputs essentially predicted an eastern distributional shift into areas of low suitability

365 between the Arica and Parinacota $\left(18^{\circ} \mathrm{S}\right)$, and the Atacama regions $\left(27^{\circ} \mathrm{S}\right)(\mathrm{Fig} .1)$. Other authors

366 have predicted similar changes in the distribution area of ungulates in arid and semi-arid

367 environments as for example, the silver dik-dik (Madoqua piacentinii, a small antelope), in the

368 southeastern coast of Somalia (Thuiller et al., 2006). In other cases, extinction risks have

369 increased with the intensification of drought episodes, as it has been seen for the hartebeest

370 (Alcelaphus buselaphus, an African antelope), and the waterbuck (Kobus ellipsiprymnus, a large

371 sub-Saharan antelope) (Duncan et al., 2012).

372 In the case of the guanaco in Chile, future distribution modeled here not only shows a 373 confinement to specific zones, such as coastal and central valleys in the Atacama region $\left(27^{\circ} \mathrm{S}\right)$,

374 and coastal and Andes Mountains between Coquimbo $\left(29^{\circ} \mathrm{S}\right)$ and Valparaíso $\left(33^{\circ} \mathrm{S}\right)$ regions, but

375 also a reduction of the distribution extent of the mixed population. This roughly coincides with

376 a predicted $5-15 \%$ rainfall reduction for the next decades between the Copiapó River $\left(27^{\circ} \mathrm{S}\right)$ and

377 the Aysén river basin (47 S) (Rojas, 2012; Garreaud et al., 2017).

378 In order to better understand spatial dynamics of guanaco's populations across their

379 distribution range, we seeked to address whether niche conservatism or divergence prevailed

380 under different climate change regimes. The basic assumption is that niches are diagnostic

381 traits that help us understanding how species deal with climate-induced changes in their

382 habitat (Wiens \& Graham, 2005; Alvarado-Serrano \& Knowles, 2014). For instance, sister

383 lineages should most likely exhibit closely similar niches, and point towards PNC (Webb et al., 
384 2002; Wiens \& Graham, 2005; Losos, 2008; Warren, Glor \& Turelli, 2008). Therefore, we

385 expected to find niche similarity (i.e. PNC) between the niches of guanaco lineages.

386 Nevertheless, we found stronger evidence for PND among L.g. cacsilensis and L.g. guanicoe,

387 hence supporting the existence of only two ESUs for the guanaco, as proposed by Marin et al.,

388 (2013): one lineage in the northwest represented by L.g. cacsilensis and another in the 389 southeast represented by L.g. guanicoe (see Table 3 and Table 4). Two interesting results 390 emerged when lineages' niches were compared with the mixed population: (i) The current

391 niche of northern L.g. cacsilensis is similar to the current niche of the mixed population; (ii) The 392 future niche of the southern L.g. guanicoe is projected to include, and resemble, the future 393 niche of the mixed population. Nevertheless, the current niche of the mixed population does 394 not share any statistically significant similarity with the northern nor the southern lineages (see 395 background similarity test results in Table 4). This suggests that L.g. cacsilensis is, given its 396 actual climatic requirements, more likely to adapt to current climatic conditions across the 397 mixed population's habitat, pointing towards the existence of PNC processes. Whereas when 398 we look at projected climate conditions, L.g. guanicoe will most likely experience a future 399 expansion of its environmental niche towards the projected mixed population's habitat. 400 Conversely, the mixed population will continue to limit its distribution to the small and 401 restricted areas of northern Chile, in spite of its recent dispersal history through extant barriers 402 (Marin et al., 2013). In summary, PNC seems to be more important when current niches are 403 analyzed, while PND emerges as the important process under future projections of climate 404 change. 
405 The high genetic variation observed for the guanaco lineage in Patagonia indicates that this

406 area may have functioned as a climatic refuge for the species (Fuentes \& Jaksic, 1979; González

407 et al., 2013). In order to safeguard the evolutionary potential of the species, conservation

408 efforts should take into consideration the projected distributions of guanaco lineages (Pecl et

409 al., 2017).

410 From our results, and under the best scenario, the current location of protected areas (PA) will

411 only decrease a 3\% of guanaco's protected distribution range, but will shift to lower quality

412 habitat, as discussed above. Projected distributions models proposed in this study are by no

413 means a prognosis of the fate of guanacos in Chile, as they outline the distribution probabilities

414 based on possible scenarios given the future GHG emissions (IPCC, 2013). Furthermore, the

415 limited geographic locations that fed our models and the uncertainties associated to GCMs

416 (Buisson et al., 2010) have likely permeated our predictions (Moss et al., 2010). In fact, the net

417 effect of our conservative forecasts may underestimate current and future species distribution

418 both within the boundaries of Chile and beyond. For instance, the species may be influenced by

419 a range of environmental conditions outside Chile that are currently not represented among

420 the presence localities in Chile. Thus, when projecting the future distribution within Chile, these

421 areas may appear as not environmentally suited for the presence of the species, altering the

422 correct estimation for the area (or percentage) of range contraction and the area (or

423 percentage) of the range in protected areas. Furthermore, addressing congruence between

424 restricted and broad scale predictions, Titeux et al., (2017) suggested that local models might

425 omit the warmest and coldest parts of future distribution, projecting a larger decrease in future

426 species richness at warmer temperatures. Therefore, the validity of the proposed distribution 
427 of guanaco's future range in Chile likely depends on the consistency between the

428 environmental niche used and the values present elsewhere, as well as on the extension of

429 guanaco's presence in extreme temperatures areas. Understanding how these observations

430 could translate to guanaco's species and lineage distribution will certainly contribute to the

431 ongoing research efforts currently underway in Argentina and Chile. Hence, it is likely that

432 efforts to expand the sampling dataset to consider guanaco's full range will also increase its

433 climate niche definition and improve the predictions of the future distribution of the species. As

434 is, the work presented represents a conservative view of guanaco's range that allows to

435 evaluate the evolutionary aspect of niche conservatism hypotheses based on the best

436 knowledge of the species natural history.

\section{Acknowledgments}

438 The authors would like to thank PeerJ editor Bruno Marino and two anonymous reviewers for

439 their suggestions, which contributed significantly to improve the original manuscript.

440

441

442

443

444

445

446

447

448

449

450

451

452

453

454

\section{References}

Acevedo P., Ward Al., Real R., Smith GC. 2010. Assessing biogeographical relationships of ecologically related species using favourability functions: A case study on British deer. Diversity and Distributions 16:515-528. DOI: 10.1111/j.1472-4642.2010.00662.x.

Alvarado-Serrano DF., Knowles LL. 2014. Ecological niche models in phylogeographic studies: Applications, advances and precautions. Molecular Ecology Resources 14:233-248. DOI: 10.1111/1755-0998.12184.

Anderson RP., Raza A. 2010. The effect of the extent of the study region on GIS models of species geographic distributions and estimates of niche evolution: Preliminary tests with montane rodents (genus Nephelomys) in Venezuela. Journal of Biogeography 37:13781393. DOI: 10.1111/j.1365-2699.2010.02290.x.

Araújo MB., New M. 2007. Ensemble forecasting of species distributions. Trends in ecology \& evolution 22:42-7. DOI: 10.1016/j.tree.2006.09.010.

Araujo MB., Rahbek C. 2006. How Does Climate Change Affect Biodiversity? Science 313:13961397. DOI: 10.1126/science.1131758. 
455

456

457

458

459

460

461

462

463

464

465

466

467

468

469

470

471

472

473

474

475

476

477

478

479

480

481

482

483

484

485

486

487

488

489

490

491

492

493

494

Araújo MB., Thuiller W., Yoccoz NG. 2009. Reopening the climate envelope reveals macroscale associations with climate in European birds. Proceedings of the National Academy of Sciences of the United States of America 106:E45-6-3. DOI: 10.1073/pnas.0813294106.

Baldi RB., Acebes P., Cuéllar E., Funes M., Hoces D., Puig S., Franklin WL. 2016.Lama guanicoe. Available at $h t t p: / / d x . d o i . o r g / 10.2305 / I U C N . U K .2016-1 . R L T S . T 11186 A 18540211 . e n$ (accessed August 17, 2017). DOI: 10.2305/IUCN.UK.2016-1.RLTS.T11186A18540211.en.

Beaumont LJ., Hughes L., Poulsen M. 2005. Predicting species distributions: Use of climatic parameters in BIOCLIM and its impact on predictions of species' current and future distributions. Ecological Modelling 186:250-269. DOI: 10.1016/j.ecolmodel.2005.01.030.

Berg MP., Toby Kiers E., Driessen G., van der Heijden M., Kooi BW., Kuenen F., Liefting M., Verhoef HA., Ellers J. 2010. Adapt or disperse: Understanding species persistence in a changing world. Global Change Biology 16:587-598. DOI: 10.1111/j.13652486.2009.02014.x.

Buisson L., Thuiller W., Casajus N., Lek S., Grenouillet G. 2010. Uncertainty in ensemble forecasting of species distribution. Global Change Biology 16:1145-1157. DOI: 10.1111/j.1365-2486.2009.02000.x.

Collins WJ., Bellouin N., Doutriaux-Boucher M., Gedney N., Halloran P., Hinton T., Hughes J., Jones CD., Joshi M., Liddicoat S., Martin G., O’Connor F., Rae J., Senior C., Sitch S., Totterdell I., Wiltshire A., Woodward S. 2011. Development and evaluation of an EarthSystem model - HadGEM2. Geoscientific Model Development 4:1051-1075. DOI: 10.5194/gmd-4-1051-2011.

Donner L., Wyman BL., Hemler RS., Horowitz LW., Ming Y., Zhao M., Golaz JC., Ginoux P., Lin SJ., Schwarzkopf MD., Austin J., Alaka G., Cooke WF., Delworth TL., Freidenreich SM., Gordon CT., Griffies SM., Held IM., Hurlin WJ., Klein SA., Knutson TR., Langenhorst AR., Lee HC., Lin Y., Magi BI., Malyshev SL., Milly PCD., Naik V., Nath MJ., Pincus R., Ploshay JJ., Ramaswamy V., Seman CJ., Shevliakova E., Sirutis JJ., Stern WF., Stouffer RJ., Wilson RJ., Winton M., Wittenberg AT., Zeng F. 2011. The dynamical core, physical parameterizations, and basic simulation characteristics of the atmospheric component AM3 of the GFDL global coupled model CM3. Journal of Climate 24:3484-3519. DOI: 10.1175/2011JCLI3955.1.

Duncan C., Chauvenet ALM., McRae LM., Pettorelli N. 2012. Predicting the Future Impact of Droughts on Ungulate Populations in Arid and Semi-Arid Environments. PLoS ONE 7. DOI: 10.1371/journal.pone.0051490.

Elith J., Graham CH., Anderson RP., Dudik M., Ferrier S., Guisan A., Hijmans RJ., Huettmann F., Leathwick JR., Lehmann A., Li J., Lohmann LG., Loiselle BA., Manion G., Moritz C., Nakamura M., Nakazawa Y., Overton JM., Peterson AT., Phillips SJ., Richardson K., Scachetti-Pereira R., Schapire RE., Soberon J., Williams S., Wisz MS., Zimmermann NE. 2006. Novel methods improve prediction of species' distributions from occurrence data. Ecography 29:129-151. DOI: 10.1111/j.2006.0906-7590.04596.x.

Elith J., Leathwick JR. 2009. Species Distribution Models: Ecological Explanation and Prediction 
495

496

497

498

499

500

501

502

503

504

505

506

507

508

509

510

511

512

513

514

515

516

517

518

519

520

521

522

523

524

525

526

527

528

529

530

531

532

Across Space and Time. Annual Review of Ecology, Evolution, and Systematics 40:677-697. DOI: 10.1146/annurev.ecolsys.110308.120159.

Fourcade Y., Engler JO., Rödder D., Secondi J. 2014. Mapping species distributions with MAXENT using a geographically biased sample of presence data: A performance assessment of methods for correcting sampling bias. PLOS ONE 9:1-13. DOI: 10.1371/journal.pone.0097122.

Franklin WL. 1982. Biology, ecology, and relationship to man of the south american camelids. In: Mares MA, Genoways HH eds. Mammalian Biology in South America. Pymatuning Lab. of Ecology,.

Franklin J. 2009. Mapping species distribution. Spatial Inference and prediction.

Franklin WL., Johnson WE., Sarno RJ., Iriarte JA. 1999. Ecology of the Patagonia puma Felis concolor patagonica in southern Chile. Biological Conservation 90:33-40. DOI: 10.1016/S0006-3207(99)00008-7.

Fuentes ER., Jaksic FM. 1979. Lizard and rodents: an explanation for their diversity in Chile. Archivos de Biología y Medicina Experimentales (Chile) 12:179-190.

Garreaud R., Alvarez-Garreton C., Barichivich J., Boisier JP., Christie D., Galleguillos M., LeQuesne C., McPhee J., Zambrano-Bigiarini M. 2017. The 2010-2015 mega drought in Central Chile: Impacts on regional hydroclimate and vegetation. Hydrology and Earth System Sciences Discussions:1-37. DOI: 10.5194/hess-2017-191.

Gent PR., Danabasoglu G., Donner LJ., Holland MM., Hunke EC., Jayne SR., Lawrence DM., Neale RB., Rasch PJ., Vertenstein M., Worley PH., Yang ZL., Zhang M. 2011. The community climate system model version 4. Journal of Climate 24:4973-4991. DOI: 10.1175/2011JCLI4083.1.

González BA., Palma RE., Zapata B., Marín JC. 2006. Taxonomic and biogeographical status of guanaco Lama guanicoe (Artiodactyla, Camelidae). Mammal Review 36:157-178. DOI: 10.1111/j.1365-2907.2006.00084.x.

González BA., Samaniego H., Marín JC., Estades CF. 2013. Unveiling Current Guanaco Distribution in Chile Based upon Niche Structure of Phylogeographic Lineages: Andean Puna to Subpolar Forests. PLOS ONE 8:e78894. DOI: 10.1371/journal.pone.0078894.

Graham CH., Ron SR., Santos JC., Schneider CJ., Moritz C. 2004. Integrating phylogenetics and environmental niche models to explore speciation mechanisms in dendrobatid frogs. Evolution 58:1781-93. DOI: 10.1111/j.0014-3820.2004.tb00461.x.

Guisan A., Thuiller W., Zimmermann NE. 2017. Habitat Suitability and Distribution Models: With Applications in R. Cambridge University Press.

Heap MJ. 2016. Introducing BioSARN - an ecological niche model refinement tool. Ecology and Evolution 6:5808-5816. DOI: 10.1002/ece3.2331.

Hijmans RJ., Cameron SE., Parra JL., Jones PG., Jarvis A. 2005. Very high resolution interpolated climate surfaces for global land areas. International Journal of Climatology 25:1965-1978. 
533

534

535

536

537

538

539

540

541

542

543

544

545

546

547

548

549

550

551

552

553

554

555

556

557

558

559

560

561

562

563

564

565

566

567

568

569

570

DOI: $10.1002 /$ joc.1276.

Hijmans RJ., Graham CH. 2006. The ability of climate envelope models to predict the effect of climate change on species distributions. Global Change Biology 12:2272-2281. DOI: 10.1111/j.1365-2486.2006.01256.x.

Hu J., Jiang Z. 2011. Climate change hastens the conservation urgency of an endangered ungulate. PLOS ONE 6. DOI: 10.1371/journal.pone.0022873.

Hu J., Jiang Z. 2012. Detecting the potential sympatric range and niche divergence between Asian endemic ungulates of Procapra. Naturwissenschaften 99:553-565. DOI: 10.1007/s00114-012-0933-1.

Hu J., Jiang Z., Chen J., Qiao H. 2015. Niche divergence accelerates evolution in Asian endemic Procapra gazelles. Scientific reports 5:10069. DOI: 10.1038/srep10069.

IPCC. 2013. Climate Change 2013. The Physical Science Basis. Contribution of Working Group I to the Fifth Assessment Report of the Intergovern- mental Panel on Climate Change.

Lenoir J., Gegout JC., Marquet PA., de Ruffray P., Brisse H. 2008. A Significant Upward Shift in Plant Species Optimum Elevation During the 20th Century. Science 320:1768-1771. DOI: 10.1126/science.1156831.

Lessa EP., Fariña RA. 1996. Reassessment of extinction patterns among the Late Pleistocene mammals of South America. Palaeontology 39:651-662.

Losos JB. 2008. Phylogenetic niche conservatism, phylogenetic signal and the relationship between phylogenetic relatedness and ecological similarity among species. Ecology letters 11:995-1003. DOI: 10.1111/j.1461-0248.2008.01229.x.

Marin JC., González B a., Poulin E., Casey CS., Johnson WE. 2013. The influence of the arid Andean high plateau on the phylogeography and population genetics of guanaco (Lama guanicoe) in South America. Molecular ecology 22:463-482. DOI: 10.1111/mec.12111.

Marin JC., Romero K., Rivera R., Johnson WE., González BA. 2017. Y-chromosome and mtDNA variation confirms indeendent demestications and directional hybridization in South America camelids. Animal Genetics:1-5. DOI: 10.1111/age.12570.

Mason THE., Stephens PA., Apollonio M., Willis SG. 2014. Predicting potential responses to future climate in an alpine ungulate: Interspecific interactions exceed climate effects. Global Change Biology 20:3872-3882. DOI: 10.1111/gcb.12641.

Merow C., Smith MJ., Silander JA. 2013a. A practical guide to MaxEnt for modeling species' distributions: What it does, and why inputs and settings matter. Ecography 36:1058-1069. DOI: 10.1111/j.1600-0587.2013.07872.x.

Merow C., Smith MJ., Silander J a. 2013b. A practical guide to MaxEnt for modeling species' distributions: what it does, and why inputs and settings matter. Ecography:no-no. DOI: 10.1111/j.1600-0587.2013.07872.x.

Metcalf JL., Turney C., Barnett R., Martin F., Bray SC., Vilstrup JT., Orlando L., Salas-Gismondi R., Loponte D., Medina M., De Nigris M., Civalero T., Fernández PM., Gasco A., Duran V., 
571

572

573

574

575

576

577

578

579

580

581

582

583

584

585

586

587

588

589

590

591

592

593

594

595

596

597

598

599

600

601

602

603

604

605

606

607

608

609

610

Seymour KL., Otaola C., Gil A., Paunero R., Prevosti FJ., Bradshaw CJA., Wheeler JC., Borrero L., Austin JJ., Cooper A. 2016. Synergistic roles of climate warming and human occupation in Patagonian megafaunal extinctions during the Last Deglaciation. Science advances 2:e1501682. DOI: 10.1126/sciadv.1501682.

Meynard CN., Gay PE., Lecoq M., Foucart A., Piou C., Chapuis MP. 2017. Climate-driven geographic distribution of the desert locust during recession periods: Subspecies' niche differentiation and relative risks under scenarios of climate change. Global Change Biology 23:4739-4749. DOI: 10.1111/gcb.13739.

Moritz C. 1994. Defining "Evolutionarily Significant Units" for conservation. Trends in Ecology \& Evolution 9:373-375. DOI: 10.1016/0169-5347(94)90057-4.

Moss RH., Edmonds JA., Hibbard KA., Manning MR., Rose SK., van Vuuren DP., Carter TR., Emori S., Kainuma M., Kram T., Meehl GA., Mitchell JFB., Nakicenovic N., Riahi K., Smith SJ., Stouffer RJ., Thomson AM., Weyant JP., Wilbanks TJ. 2010. The next generation of scenarios for climate change research and assessment. Nature 463:747-756. DOI: 10.1038/nature08823.

Muñoz-Mendoza C., D’Elía G., Panzera A., Méndez T. MA., Villalobos-Leiva A., Sites JW., Victoriano PF. 2017. Geography and past climate changes have shaped the evolution of a widespread lizard from the Chilean hotspot. Molecular Phylogenetics and Evolution 116:157-171. DOI: 10.1016/j.ympev.2017.08.016.

Nazarenko L., Schmidt GA., Miller RL., Tausnev N., Kelley M., Ruedy R., Russell GL., Aleinov I., Bauer M., Bauer S., Bleck R., Canuto V., Cheng Y., Clune TL., Del Genio AD., Faluvegi G., Hansen JE., Healy RJ., Kiang NY., Koch D., Lacis AA., Legrande AN., Lerner J., Lo KK., Menon S., Oinas V., Perlwitz J., Puma MJ., Rind D., Romanou A., Sato M., Shindell DT., Sun S., Tsigaridis K., Unger N., Voulgarakis A., Yao MS., Zhang J. 2015. Future climate change under RCP emission scenarios with GISS ModelE2. Journal of Advances in Modeling Earth Systems 7:244-267. DOI: 10.1002/2014MS000403.

Pecl GT., Araújo MB., Bell JD., Blanchard J., Bonebrake TC., Chen I-C., Clark TD., Colwell RK., Danielsen F., Evengård B., Falconi L., Ferrier S., Frusher S., Garcia RA., Griffis RB., Hobday AJ., Janion-Scheepers C., Jarzyna MA., Jennings S., Lenoir J., Linnetved HI., Martin VY., McCormack PC., McDonald J., Mitchell NJ., Mustonen T., Pandolfi JM., Pettorelli N., Popova E., Robinson SA., Scheffers BR., Shaw JD., Sorte CJB., Strugnell JM., Sunday JM., Tuanmu M-N., Vergés A., Villanueva C., Wernberg T., Wapstra E., Williams SE. 2017. Biodiversity redistribution under climate change: Impacts on ecosystems and human wellbeing. Science 355:eaai9214. DOI: 10.1126/science.aai9214.

Peterson AT., Soberón J., Sánchez-cordero V. 1999. Conservatism of Ecological Niches in Evolutionary Time. Science 285:1265-1267. DOI: 10.1126/science.285.5431.1265.

Phillips SJ., Anderson RP., Schapire RE. 2006. Maximum entropy modeling of species geographic distributions. Ecological Modelling 190:231-259. DOI: 10.1016/j.ecolmodel.2005.03.026.

Phillips SJ., Dudík M. 2008. Modeling of species distribution with Maxent: new extensions and a comprehensive evalutation. Ecograpy 31:161-175. DOI: 10.1111/j.2007.0906- 
611

612

613

614

615

616

617

618

619

620

621

622

623

624

625

626

627

628

629

630

631

632

633

634

635

636

637

638

639

640

641

642

643

644

645

646

647

648

649

Phillips SJ., Dudík M., Schapire RE. 2004. A maximum entropy approach to species distribution modeling. 21st International Conference on Machine Learning, Banff, Canada:655-662. DOI: 10.1145/1015330.1015412.

Pyron RA., Costa GC., Patten MA., Burbrink FT. 2015. Phylogenetic niche conservatism and the evolutionary basis of ecological speciation. Biological Reviews. DOI: 10.1111/brv.12154.

Quevedo P., von Hardenberg A., Pastore H., Álvarez J., Corti P. 2016. Predicting the potential distribution of the Endangered huemul deer Hippocamelus bisulcus in North Patagonia. Oryx:1-9. DOI: 10.1017/S0030605315001106.

Quintero I., Wiens JJ. 2013. Rates of projected climate change dramatically exceed past rates of climatic niche evolution among vertebrate species. Ecology Letters 16:1095-1103. DOI: 10.1111/ele.12144.

Rojas M. 2012. Consultoría para la elaboración de un estudio sobre el estado del arte de modelos para la investigación del calentamiento global (Informe para Opciones de Mitigación para enfrentar el Cambio Climático, MAPS Chile).

Shrestha UB., Bawa KS. 2014. Impact of climate change on potential distribution of Chinese caterpillar fungus (Ophiocordyceps sinensis) in Nepal Himalaya. PLoS ONE 9. DOI: 10.1371/journal.pone.0106405.

Squeo FA., Warner BG., Aravena R., Espinoza D. 2006. Bofedales : high altitude peatlands of the central Andes. Revista Chilena de Historia Natural 79:245-255.

Swets J. 1988. Measuring the accuracy of diagnostic systems. Science 240:1285-1293. DOI: $10.1126 /$ science. 3287615 .

Taylor KE., Stouffer RJ., Meehl GA. 2012. An overview of CMIP5 and the experiment design. Bulletin of the American Meteorological Society 93:485-498. DOI: 10.1175/BAMS-D-1100094.1.

Thomas CD., Thomas CD., Cameron A., Cameron A., Green RE., Green RE., Bakkenes M., Bakkenes M., Beaumont LJ., Beaumont LJ., Collingham YC., Collingham YC., Erasmus BFN., Erasmus BFN., De Siqueira MF., De Siqueira MF., Grainger A., Grainger A., Hannah L., Hannah L., Hughes L., Hughes L., Huntley B., Huntley B., Van Jaarsveld AS., Van Jaarsveld AS., Midgley GF., Midgley GF., Miles L., Miles L., Ortega-Huerta M a., Ortega-Huerta M a., Peterson a T., Peterson a T., Phillips OL., Phillips OL., Williams SE., Williams SE. 2004. Extinction risk from climate change. Nature 427:145-8. DOI: 10.1038/nature02121.

Thuiller W., Broennimann O., Hughes G., Alkemade JRM., Midgley GF., Corsi F. 2006. Vulnerability of African mammals to anthropogenic climate change under conservative land transformation assumptions. Global Change Biology 12:424-440. DOI: 10.1111/j.1365-2486.2006.01115.x.

Thuiller W., Brotons L., Araújo MB., Lavorel S. 2004. Effects of restricting environmental range of data to project current and future species distributions. Ecography 27:165-172. DOI: 10.1111/j.0906-7590.2004.03673.x. 
650 Titeux N., Maes D., Van Daele T., Onkelinx T., Heikkinen RK., Romo H., García-Barros E., 651 Munguira ML., Thuiller W., van Swaay CAM., Schweiger O., Settele J., Harpke A., Wiemers

652

653

654

655

656

657

658

659

660

661

662

663

664

665

666

667

668

669

670

671

672

673

674

675

676

677

678

679 M., Brotons L., Luoto M. 2017. The need for large-scale distribution data to estimate regional changes in species richness under future climate change. Diversity and Distributions. DOI: 10.1111/ddi.12634.

Travaini A., Donázar JA., Ceballos O., Hiraldo F. 2001. Food habits of the Crested Caracara (Caracara plancus) in the Andean Patagonia: the role of breeding constraints. Journal of Arid Environments 48:211-219. DOI: 10.1006/jare.2000.0745.

Urban MC. 2010. Accelerating extinction risk from climate change. Science 348:571-573. DOI: 10.1111/1467-8322.12302.

Walther G., Post E., Convey P., Menzel A., Parmesan C., Beebee TJC., Fromentin J-M., HoeghGuldberg O., Bairlein F. 2002. Ecological responses to recent climate change. Nature 416:389-395. DOI: 10.1038/416389a.

Warren DL., Glor RE., Turelli M. 2008. Environmental niche equivalency versus conservatism: quantitative approaches to niche evolution. Evolution 62:2868-83. DOI: 10.1111/j.15585646.2008.00482.x.

Warren DL., Glor RE., Turelli M. 2010. ENMTools: a toolbox for comparative studies of environmental niche models. Ecography 1:607-611. DOI: 10.1111/j.16000587.2009.06142.x.

Warren R., VanDerWal J., Price J., Welbergen JA., Atkinson I., Ramirez-Villegas J., Osborn TJ., Jarvis A., Shoo LP., Williams SE., Lowe J. 2013. Quantifying the benefit of early climate change mitigation in avoiding biodiversity loss. Nature Climate Change 3:678-682. DOI: $10.1038 /$ nclimate1887.

Webb CO., Ackerly DD., McPeek MA., Donoghue MJ. 2002. Phylogenies and Community Ecology. Annual Review of Ecology and Systematics 33:475-505. DOI: 10.1146/annurev.ecolsys.33.010802.150448.

Wiens JJ., Graham CH. 2005. Niche Conservatism: Integrating Evolution, Ecology, and Conservation Biology. Annual Review of Ecology, Evolution, and Systematics 36:519-539. DOI: 10.1146/annurev.ecolsys.36.102803.095431. 


\section{Figure 1 (on next page)}

Current and projected distribution model of guanaco lineages in South America.

A) current distribution; and projected distributions B) under RCP2.6 to 2050; C) under RCP2.6 to 2070; D) under RCP8.5 to 2050; E) under RCP8.5 to 2070. These surfaces were classified according to habitat suitability. Base Map Elevation Data: CIAT-CSI SRTM (http://srtm.csi.cgiar.org). 

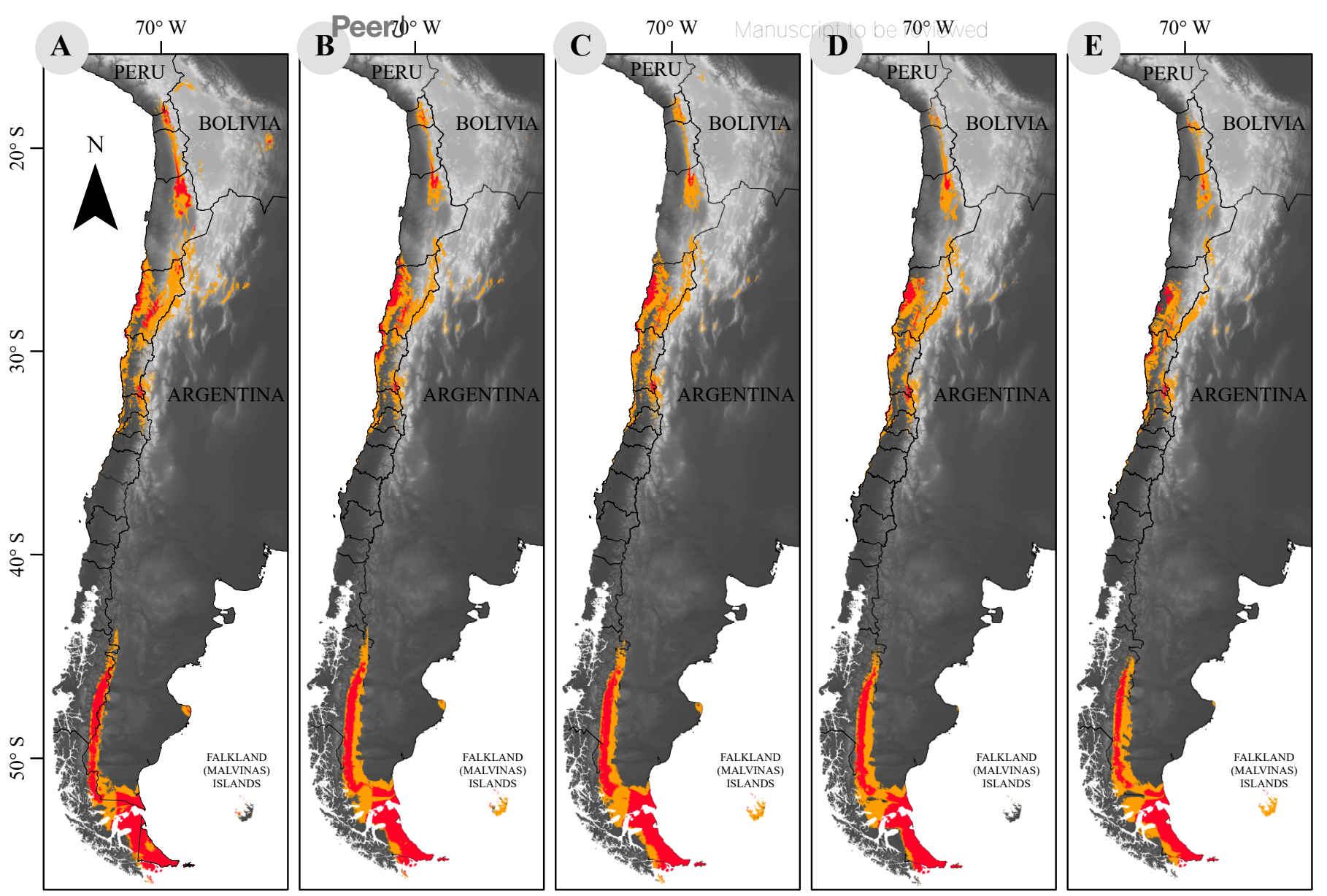

Low (25-50\%) Medium (50-75\%)

High (>75\%) 


\section{Figure 2 (on next page)}

\section{Cartographic projection of changes in distribution.}

Pink surface corresponds to areal loss and representing the areal fraction of the climatic niche that exists only in the current model. Olive surface corresponds to areal gains and represents the climatic niche area that exists only in the projected model. Orange surface corresponds to the area that has remained unchanged and represents the surface of the climatic niche that exists in both models (current and projected models). Panel A is the comparison between current and projected model under RCP2.6 to 2050; $B$, the comparison between current and projected model under RCP2.6 to 2070; C, the Comparison between current and projected model under RCP8.5 to 2050; D, is the comparison between current and projected model under RCP8.5 to 2070. Base Map Elevation Data: CIAT-CSI SRTM (http://srtm.csi.cgiar.org). 


\section{Figure 3 (on next page)}

Overlap between projected environmental niche models under two extreme climate scenarios and distribution of protected areas in Chile.

$A$ and $B$ are projections based on RCP2.6 scenarios; C and D correspond to RCP8.5 scenarios. Protected categories consider National Parks, National Reserves, Biosphere Reserves, National Monuments, Protected National Heritage, RAMSAR sites (2012), and Private Protected Areas (2011) (IDE, 2016). Base Map Elevation Data: CIAT-CSI SRTM (http://srtm.csi.cgiar.org). 


\section{Table $\mathbf{1}$ (on next page)}

Geographic distribution area $\left(\mathrm{km}^{2}\right)$ of current potential distribution of $L$. guanicoe across habitat suitability categories.

Environmental niche models are projected to years 2050 and 2070 under the most extreme greenhouse gas emission scenarios. RCP2.6 represents climate model under the less severe emission scenario and RCP8.5 the scenario under the largest greenhouse gas emission. Letters in parentheses show corresponding panel in Fig. 1. 
1

\begin{tabular}{|l|r|r|r|r|r|}
\hline & & \multicolumn{2}{|c|}{ RCP2.6 } & \multicolumn{2}{|c|}{ RCP 8.5} \\
\hline Suitability category & Current (A) & $2050(\mathrm{~B})$ & $2070(\mathrm{C})$ & 2050 (D) & 2070 (E) \\
\hline High (>75\%) & 23 & 71 & 258 & 3 & 0 \\
\hline Medium (50-75\%) & 102,693 & 94,574 & 88,295 & 80,653 & 66,344 \\
\hline Low (25-50\%) & 173,353 & 164,932 & 166,427 & 159,849 & 152,497 \\
\hline Total & 276,069 & 259,577 & 254,979 & 240,505 & 218,841 \\
\hline
\end{tabular}

2 


\section{Table 2 (on next page)}

Percent change of distribution area between current and projected models for 2050 and 2070 under the most extreme climate change projections.

Areal losses, unchanged and gains in square kilometers for each RCP model with respect to current potential distribution of guanaco. Percentage changes are shown in parentheses. Letters in parentheses after the year, refer to panels of Fig. 2. 
1

\begin{tabular}{|l|r|r|r|r|}
\hline & \multicolumn{2}{|c|}{ RCP2.6 } & \multicolumn{2}{c|}{ RCP8.5 } \\
\hline & $2050(\mathrm{~A})$ & $2070(\mathrm{~B})$ & $2050(\mathrm{C})$ & 2070 (D) \\
\hline Losses $\left(\mathrm{km}^{2}\right)$ & $66,634(24 \%)$ & $67,450(24 \%)$ & $86,540(31 \%)$ & $103,367(37 \%)$ \\
\hline Unchanged $\left(\mathrm{km}^{2}\right)$ & $209,519(76 \%)$ & $208,703(76 \%)$ & $189,613(69 \%)$ & $172,786(63 \%)$ \\
\hline Gains $\left(\mathrm{km}^{2}\right)$ & $50,106(18 \%)$ & $46,343(17 \%)$ & $50,968(18 \%)$ & $46,089(17 \%)$ \\
\hline
\end{tabular}

2 


\section{Table 3(on next page)}

Niche identity test.

These results correspond to the comparison between the empirical values (niche overlap) and values of percentiles 0.1 of the null distribution (one tailed, Warren, Glor \& Turelli, 2010). The "I" and " $D$ " statistics allow to compare the overlap between the replicas of this test. If the empirical value is within the range of values observed in the percentages, the hypothesis of niche equivalence is supported (shown in bold type). 
1

\begin{tabular}{|c|c|c|c|c|c|}
\hline \multirow[t]{2}{*}{ Niche model } & \multirow[t]{2}{*}{ Compared lineages } & \multicolumn{2}{|c|}{$\begin{array}{l}\text { Empirical value } \\
\text { (Niche overlap) }\end{array}$} & \multicolumn{2}{|c|}{$\begin{array}{c}\text { Identity test } \\
\text { (Niche equivalence) }\end{array}$} \\
\hline & & I & $D$ & I & $D$ \\
\hline \multirow{3}{*}{ Current } & L. g. cacsilensis - Mixed population & 0.283 & 0.089 & 0.923 & 0.686 \\
\hline & L. g. guanicoe - Mixed population & 0.178 & 0.058 & 0.922 & 0.711 \\
\hline & L. g. cacsilensis - L. g. guanicoe & 0.133 & 0.033 & 0.922 & 0.596 \\
\hline \multirow{3}{*}{ Projected (2070) } & L. g. cacsilensis - Mixed population & 0.471 & 0.208 & 0.930 & 0.760 \\
\hline & L. g. guanicoe - Mixed population & 0.135 & 0.039 & 0.950 & 0.800 \\
\hline & L. g. cacsilensis - L. g. guanicoe & 0.090 & 0.015 & 0.890 & 0.630 \\
\hline
\end{tabular}

2 


\section{Table 4 (on next page)}

Background similarity test.

The first column indicates whether the analysis was applied on current or projected niche models. Second and third columns indicate compared lineages and focal lineage used for the comparison. These results show the comparison between the empirical values (niche overlap results) and 0.1 and 0.9 percentiles of the null distribution (two tailed, Warren, Glor \& Turelli, 2010) delivered by the test. If the empirical value is within the range of values observed in the percentages, the hypothesis of niche similarity is supported (shown in bold type). 
1

\begin{tabular}{|c|c|c|c|c|c|c|c|c|}
\hline & \multicolumn{2}{|c|}{ Pair compared } & \multicolumn{2}{|c|}{ Niche overlap } & \multicolumn{4}{|c|}{ Background similarity test } \\
\hline \multirow{2}{*}{$\begin{array}{l}\text { Niche } \\
\text { Model }\end{array}$} & \multirow[b]{2}{*}{ Focal } & \multirow[b]{2}{*}{ Background } & \multirow[b]{2}{*}{$D$} & \multirow[b]{2}{*}{ I } & \multicolumn{2}{|c|}{$p=0.01$} & \multicolumn{2}{|c|}{$p=0.90$} \\
\hline & & & & & $D$ & I & $D$ & I \\
\hline \multirow[t]{6}{*}{ Current } & $\begin{array}{c}\text { L.g. } \\
\text { cacsilensis }\end{array}$ & $\begin{array}{c}\text { Mixed } \\
\text { population }\end{array}$ & 0.089 & 0.283 & 0.082 & 0.260 & 0.115 & 0.320 \\
\hline & $\begin{array}{c}\text { Mixed } \\
\text { population }\end{array}$ & $\begin{array}{c}\text { L.g. } \\
\text { cacsilensis }\end{array}$ & 0.089 & 0.283 & 0.094 & 0.304 & 0.108 & 0.336 \\
\hline & $\begin{array}{c}\text { L.g. } \\
\text { guanicoe }\end{array}$ & $\begin{array}{c}\text { Mixed } \\
\text { population }\end{array}$ & 0.058 & 0.133 & 0.136 & 0.358 & 0.140 & 0.366 \\
\hline & $\begin{array}{c}\text { Mixed } \\
\text { population }\end{array}$ & L. g. guanicoe & 0.058 & 0.133 & 0.091 & 0.302 & 0.107 & 0.332 \\
\hline & $\begin{array}{c}\text { L.g. } \\
\text { cacsilensis }\end{array}$ & L. g. guanicoe & 0.033 & 0.178 & 0.091 & 0.273 & 0.124 & 0.332 \\
\hline & $\begin{array}{c}\text { L.g. } \\
\text { guanicoe }\end{array}$ & $\begin{array}{c}\text { L.g. } \\
\text { cacsilensis }\end{array}$ & 0.033 & 0.178 & 0.136 & 0.359 & 0.141 & 0.368 \\
\hline \multirow[t]{4}{*}{$\begin{array}{l}\text { Projected } \\
(2070)\end{array}$} & $\begin{array}{c}\text { L.g. } \\
\text { cacsilensis }\end{array}$ & $\begin{array}{c}\text { Mixed } \\
\text { population }\end{array}$ & 0.208 & 0.471 & 0.158 & 0.387 & 0.169 & 0.410 \\
\hline & $\begin{array}{c}\text { Mixed } \\
\text { population }\end{array}$ & $\begin{array}{c}\text { L.g. } \\
\text { cacsilensis }\end{array}$ & 0.208 & 0.471 & 0.055 & 0.211 & 0.074 & 0.251 \\
\hline & $\begin{array}{c}\text { L.g. } \\
\text { guanicoe }\end{array}$ & $\begin{array}{c}\text { Mixed } \\
\text { population }\end{array}$ & 0.039 & 0.135 & 0.033 & 0.123 & 0.042 & 0.148 \\
\hline & $\begin{array}{c}\text { Mixed } \\
\text { population }\end{array}$ & L. g. guanicoe & 0.039 & 0.135 & 0.011 & 0.055 & 0.016 & 0.072 \\
\hline
\end{tabular}


2

\begin{tabular}{|c|c|c|c|c|c|c|c|c|}
\hline & $\begin{array}{c}\text { L.g. } \\
\text { cacsilensis }\end{array}$ & L.g. guanicoe & 0.015 & 0.090 & 0.006 & 0.042 & 0.010 & 0.058 \\
\cline { 2 - 8 } & $\begin{array}{c}\text { L.g. } \\
\text { guanicoe }\end{array}$ & $\begin{array}{c}\text { L.g. } \\
\text { cacsilensis }\end{array}$ & 0.015 & 0.090 & 0.018 & 0.080 & 0.020 & 0.085 \\
\hline
\end{tabular}

